\begin{tabular}{l} 
2. To: (Receiving Organization) \\
Dist $x$ jbution \\
\hline 5. Proj./Prog./Dept./Div.: \\
241-U/SN-216/ISE
\end{tabular}

8. Originator Remarks:

This EDT documents the formal design review of ECN 638584 for the reconnection of SN-216 to U-D Valve Pit. The reconnection will bypass the U Earm DCRT for the purpose of saltwell pumping of U-Farm for a direct route to SY 102 .

11. Receiver Remarks: 11A. Design Baseline Document? $O$ Yes $\bigcirc$ No

4. Related EDT No:

$\mathrm{N} / \mathrm{A}$

7. Purchase Order No.:

$\mathrm{N} / \mathrm{A}$

9. Equip./Component No.:

$\mathrm{SN}-216$

10. System/Bldg./Facility:

241-Ü/SN-216

12. Major Assm. Dwg. No.:

$\mathrm{N} / \mathrm{A}$

13. Permit/Permit Application No.:

14. Required Response Date:

$\mathrm{N} / \mathrm{A}$

\begin{tabular}{|c|c|c|c|c|c|c|c|c|}
\hline 15. & & DATA TR & NSMITTE & & (F) & (G) & $(\mathrm{H})$ & (I) \\
\hline $\begin{array}{l}\text { (A) } \\
\text { Item } \\
\text { No. }\end{array}$ & (B) Document/Drawing No. & $\begin{array}{l}\text { (C) Sheet } \\
\text { No. }\end{array}$ & $\begin{array}{l}\text { (D) Rev. } \\
\text { No. }\end{array}$ & (E) Title or Description of Data Transmitted & $\begin{array}{l}\text { Approval } \\
\text { Desig- } \\
\text { nator }\end{array}$ & $\begin{array}{c}\text { Reason } \\
\text { for Trans- } \\
\text { mittal }\end{array}$ & $\begin{array}{c}\text { Origi- } \\
\text { nator } \\
\text { Dispo- } \\
\text { stion }\end{array}$ & $\begin{array}{c}\text { Receiv- } \\
\text { er } \\
\text { Dispo- } \\
\text { sition }\end{array}$ \\
\hline 1 & HNF-4568 & NA & 0 & Reconnect SN-216 to U-D & $\mathrm{N} / \mathrm{A}$ & 2 & 1 & 1 \\
\hline & & & & Valve Pit Design Review & & & & \\
\hline & & & & & & & & \\
\hline & & & & & & & & \\
\hline & & & & & & & & \\
\hline & & & & & & & & \\
\hline & & & & & & & & \\
\hline
\end{tabular}

16.

\begin{tabular}{c|ll}
\hline Approval Designator (F) & \multicolumn{1}{c}{ Reason for Transmittal (G) } \\
\hline E, S, Q, D OR N/A & 1. Approval & 4. Review \\
(See WHC-CM-3-5, & 2. Release & 5. Post-Review \\
Sec. 12.7) & 3. Information & 6. Dist. (Receipt Acknow. Required)
\end{tabular}

SIGNATURE/DISTRIBUTION

(See Approval Designator for required signatures)

17.

\begin{tabular}{ll|l|c|l} 
(L) Date & (M) MSIN & Rea- & $\left(\begin{array}{c}(\mathrm{H}) \\
\text { Disp. }\end{array}\right.$ & (J) Name
\end{tabular}

1. Approved

2. Approved w/comment 3. Disapproved w/comment
Disposition (H) \& (l)

4. Reviewed no/comment 5. Reviewed w/comment 6. Receipt acknowledged

\begin{tabular}{|c|c|c|}
\hline $\begin{array}{c}\text { (G) } \\
\text { Rea- } \\
\text { son }\end{array}$ & $\begin{array}{c}(\mathrm{H}) \\
\text { Disp. }\end{array}$ & (L) Date (M) MSIN \\
\hline 1 & 1 & Design Authority $R F$ \\
\hline 3 & 1 & Design Agent JJ Elsen \\
\hline 3 & 1 & Cog. Eng. KJ Hull / JhPll 6/29, 1999 \\
\hline 1 & 1 & Cog.Mgr. RE Larsen REJawa $1 / 2 q / 99$ T40 \\
\hline 3 & 1 & MA Tipps \\
\hline 3 & 1 & Safety LS Krogsrud \\
\hline 3 & 1 & Env. $\quad$ QC Miller \\
\hline
\end{tabular}
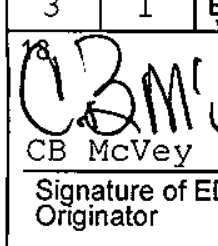

CB McVey

Signature of

BD-7400-172-2(10/97)

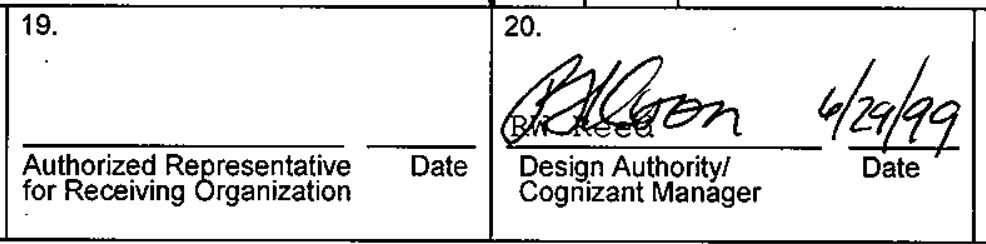

21. DOE APPROVAL (if required)

Ctrl No. N/A

Approved

Approved w/comments

Disapproved w/comments 


\title{
RECONNECTION OF SN-216 TO U-D VALVE PIT DESIGN REVIEW
}

\author{
CB MCVEY \\ LOCKHEED MARTIN HANFORD CORPORATION \\ Richland, WA 99352 \\ U.S. Department of Energy Contract DE-AC06-96RL13200
}

$\begin{array}{lll}\text { EDT/ECN: } & 626386 & \text { UC: } 500 \\ \text { Org Code: } & 74 \text { DOO } & \text { Charge Code: } 109351 \\ \text { B\&R Code: } & \text { EW3120071 } & \text { Total Pages: } 20\end{array}$

Key Words: SN-216, U-D VALVE PIT, TRANSFER IINE, DCRT

Abstract: The design for the reconnection of SN-216 to U-D valve pit was reviewed on May 24, 1999. All Review Comment Record comments were resolved and closed at this meeting. The review concluded that the reconnection of $\mathrm{SN}-216$ to U-D valve pit was acceptable. The design was approved with the incorporated comments as recorded on the RCR's. No outstanding comments remain.

TRADEMARK DISCLAIMER. Reference herein to any specific commercial product, process, or service by trade name, trademark, manufacturer, or otherwise, does not necessarily constitute or imply its endorsement, recommendation, or favoring by the United States Government or any agency thereof or its contractors or subcontractors.

Printed in the United States of America. To obtain copies of this document, contact: Document Control Services, P.O. Box 950, Mailstop H6-08, Richland WA 99352, Phone (509) 372-2420; Fax (509) 376-4989.

$\frac{\text { Ginesuaden } \quad 7 / 7 / 99}{\text { Release Approval }}$

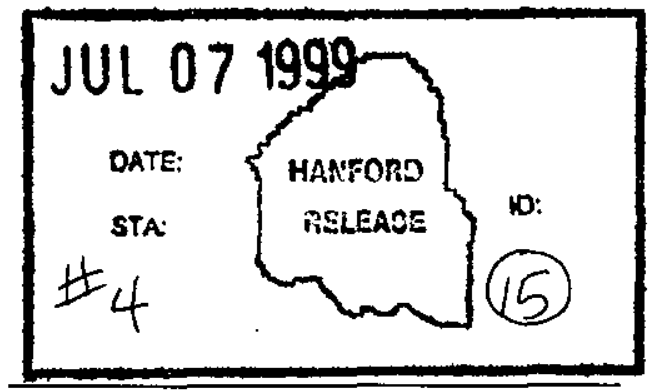

Release Stamp 
TABLE OF CONTENTS

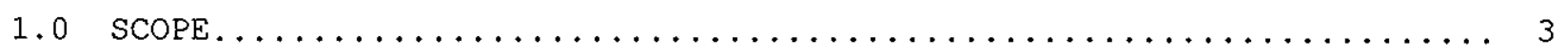

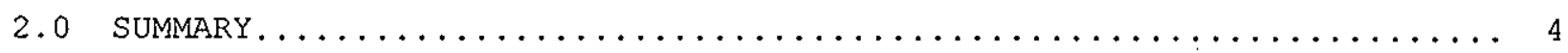

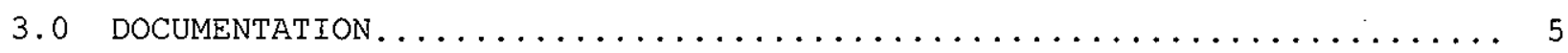

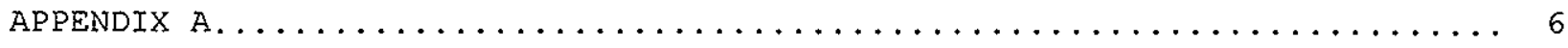

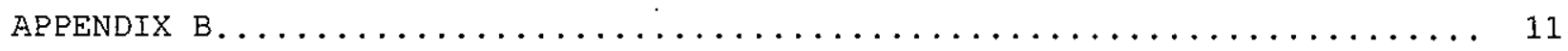

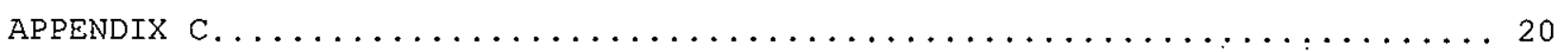




\subsection{SCOPE}

A design review meeting was held to review ECN 638584. During the review meeting all RCR's were reviewed and disposition to the satisfaction of the reviewers. The review covered the reconnection of SN-216 line to the U-D valve pit. All comments and their dispositions are covered in the attached meeting minutes. No outstanding comments remain.

$\begin{array}{ll}\text { Documents Reviewed: 1) } & \text { ECN-638584, Reconnect SN-216 to U-D Valve } \\ \text { Rit }\end{array}$

The ECN provided the description of the reconnection of SN-216. The reconnection of this line will allow for the bypass of the 241-U DCRT. The DCRT has never been used for waste transfers and would require extensive modification to meet existing regulations. This modification to SN-216 will allow a route to SY-102, which allows for continuous saltwell pumping of multiple tanks in U-Farm without passing through the DCRT. The route through the DCRT would require numerous shutdowns to pump out the DCRT when it was filled. Also by changing the route around the DCRT, flammable gas issues will be avoided at the DCRT.

All objectives of the review were to establish design approval for the reconnection of SN-216 line to the U-D Valve Pit. 


\subsection{SUMMARY}

A design review briefing was held on 5/17/99. The briefing outline the description of the ECN 638584. A review of the technical items of concern was discussed and comments were generated and are covered in the meeting minutes in Appendix A.

The design review meeting was held on 5/25/99. The meeting minutes are attached in Appendix B. Comments were recorded on Review Comment Records (Appendix C) and in the meeting minutes. No further comments were made. The conclusion of the meeting was that the design for the reconnection of SN-216 line to the U-D valve pit was acceptable.

No outstanding action items remain on the design. 


\title{
3.0 DOCUMENTATION
}

Design Review Committee Members:
G. P. Reed
R. E. Larsen
K. J. HuIl
M. C. Tipps
L. S. Krogsrud
P. C. Millex
M. R. Koch
J. J. Elsen
C. B. McVey

\author{
Design Authority \\ Cognizant Manager \\ Cognizant Engineer - U Farm \\ Quality Assurance \\ Safety \\ Environmental \\ Cognizant Managex - ISE \\ Design Engineer \\ Design Review Chaixman
}

Documents:

Meeting Minutes, Distribution, dated 5/17/99

Meeting Minutes, Distribution, dated 5/24/99 
APPENDIX A

MEETING MINUTES

DESIGN REVIEW MEETING ECN 638584

RECONNECT SN-216 TO U-D VALVE PIT 


\section{MEETING MINUTES}

SUBJECT: Formal Design Review Briefing

\begin{tabular}{|l|l|l|l|l|l|}
\hline TO: & \multicolumn{1}{|l}{ BUILDING } \\
Distribution & MO-281 \\
\hline FROM: & CHAIRMAN \\
Interim Stabilization Engineering & Chuck McVey \\
\hline DEPARTMENT-OPERATION-COMPONENT & AREA & SHIFT & $\begin{array}{c}\text { DATE OF MEETING } \\
05 / 17 / 99\end{array}$ & $\begin{array}{c}\text { NUMBER ATTENDING } \\
8\end{array}$ \\
\hline
\end{tabular}

Formal Design Review Team:

John J. Elsen*

Kevin J. Hull *

Mike R. Koch*

Laroy $S$. Krosgrud*

Rich E. Larson*

Phil C. Millex

Ron W. Reed*

Mike C. Tipps

Chuck C. McVey*

George J. Coleman*

Kelly R. Ellingson*

Attendees*

Chuck McVey opened the meeting with the following:

This Formal Design Review Briefing was held to discuss ECN \#638584 "Reconnect SN-216/282 to U-D Valve Pit. Stabilization of U-Farm will bypass the existing DCRT, in favor of a direct piping route between $U-D$ valve pit and SY-B valve pit. This transfer line SN-216/282 must be disconnected from the DCRT and reconnected to the U-D valve pit. ECN \#101540 and EO \#4642 are being superseded. Field work of these two documents is believed to have been completed but not signed as completed. The work of these two changes will be negated by the completion of field work performed by this ECN.

1.) Routing details of DCRT were discussed.

2.) RCR comments were generated from discussion and are listed below:

2.1 Steve Krogsrud - No comments

2.2 George Coleman - No comments

2.3 Kevin Hull - Comment: USQ number needs to be on ECN

Response: There is a USQ number assigned and will be added on ECN.

Comment: List ECNs that are superseded by this ECN.

Response: ECN numbers will be listed on this ECN

Comment: This ECN \#638584 will need to indicate supplemental and supersedure in block 2 .

Response: Agreed

Comment: In justification block 146 replace the word voided with negated.

Response: Agreed 


\section{$H N F-4568$ REVD page 8 of 20}

MEETING MINUTES (Continued)

Page 2 of 2

Comment: In justification block 146 change typo from "or" to "of". Response: Agreed

2.4 Rich Laxson: Comment: Block 20 of this ECN, identify documents to be affected. Response: Agreed

Comment: This ECN needs to include design review chairman.

Response: Agreed

Comment: Page 7 of this ECN, what is maximum pressure of pump that can be set?

Response: 187 lbs.

2.5 Mike Koch: Comment: Where is the diversion box?

Response: East of 241-S-102 and West of the evaporator.

Comment: U-Farm requires no dilution it is below the criteria, but Process Engineering is still evaluating the need to prevent plugging.

2.6 Ron Reed: Comment: Heat Trace is not included on this ECN.

Response: Heat Trace will be on a separate ECN.

Comment: Confirm chemical addition requirements. (hold point)

Response: Mike Koch will confirm this with Process Engineering.

Comment: Line should be tested to design pressure of 400 psi plus 200 psi for safety factor for a total of 600 psi.

Since a plug is possible the line may experience 600 lbs. for unplugging and we should know if the line can handle this pressure.

Response: This will be evaluated.

2.7 Kevin Hull Comment: Page 4 of this ECN, view 5, quartex inch plate shows weld encasement pipe, but does not show inner weld.

Response: Inner weld will be added.

3.0 A Formal Design Review Meeting will be held on May 24, at 10:00am at Mo-281, Room 130 . 


\section{MEETING MINUTES}

SUBJECT: Formal Design Review ECN \#638584, Reconnect SN-216 to U-D Valve Pit

\begin{tabular}{|c|c|c|c|c|}
\hline TO: & & BUILD & & \\
\hline Distribution & & 270 & & \\
\hline $\begin{array}{l}\text { FROM: } \\
\text { ISE }\end{array}$ & & $\begin{array}{l}\text { CHAIF } \\
\text { C. }\end{array}$ & ey & 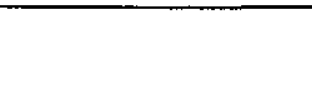 \\
\hline DEPARTMENT-OPERATION-COMPONENT & $\begin{array}{l}\text { AREA } \\
200 E\end{array}$ & SHIFI & $\begin{array}{c}\text { DATE OF MEETING } \\
05 / 24 / 99\end{array}$ & $\begin{array}{c}\text { NUMBER ATTENDING } \\
8\end{array}$ \\
\hline
\end{tabular}

Formal Design Review Committee:

J. J. Elsen*

M. R. KoCh*

L. S. Krogsrud*

R. E. Larson

P. C. Miller* (Scott Conrad in attendance for Miller)

C. B. McVey*

R. W. Reed*

M. A. Tipps*

K. R. Ellingson*

Attendees*

C. B. McVey opened with the following:

1.) This formal design review was held to disposition comments for ECN \#638584, "Reconnect SN-216/282 to U-D Valve pit.

2.) Phil Miller RCR, signed: No comment

3.) Mike Tipps RCR, signed: No comment

4.) Kevin Hull RCR, signed: 1.) USQ number needs to be on the ECN.

Disposition: Agreed

Status: closed

2.) List ECNs that are superseded by this ECN.

Disposition: Agreed

Status: Closed

3.) In the justification block $14 \mathrm{~b}$ replace the word voided with negated.

Disposition: Agreed

Status: Closed

4.) Page 4 of $\mathrm{ECN}$, view 5, quarter inch plate shows weld encasement pipe but does not show inner weld.

Disposition: Agreed

Status: Closed

5.) Mike Koch RCR, signed: 1.) U-farm originally requires no dilution since it is below the criteria, but process engineering is still evaluating the need for dilution to prevent plugging.

Disposition: Comment only. A dilution system is being designed to accommodate P.E. requirements.

Status: Closed

Hold Point: No 
6.) Steve Krogsrud RCR, signed

7.) Ronald Reed/Mark Brown RCR, signed: 1.) Heat trace is not included on this ECN. Disposition: Reject, heat trace will be on a separate ECN dependent upon as found field condition.

Status: Closed

2.) Confirm chemical addition requirements and location of mixing.

Disposition: Accept

Status: Closed

Hold Point: Yes

3.) Primary line should be tested for a design pressure of $400 \mathrm{psi}$. Hydro test primary to 600 psi.

Disposition: Accept, Since a plug is possible the line may experience elevated pressures for unplugging. Hydro test should prove line integrity o $600 \mathrm{psi}$ (primary) and e $90 \mathrm{psi}$ (encasement)

Status: Closed

4.) Is there a project associated with the old work? Disposition: Yes, B-533 and B-231

Status: Closed

5.) Is drawing $\mathrm{H}-2-31750$ to be used for the pipe code materials.

Disposition: Yes, identical material will be called out in detail 9 of ECN.

Status: Closed

6.) On page 4 change plate to go over the encasement, this will reduce the tight tolerance and ease fabrication

Disposition: Accept

status: Closed

7.) On page 4 note 1, "and.... and or butt welded

Disposition: Reject, note 1 wording clarified. Weld material detail on cap specified socket weld.

Status: Closed

8.) On page 7 add melt through on weld symbol Disposition: Reject, melt through reinforcement not needed.

Status: Closed

1.) No comment

1.) Block 20 of $\mathrm{ECN}$ identify documents to be affected.

Disposition: Agreed

Status: Closed

2.) ECN needs to include the design review chairman Disposition: Agreed

Status: Closed

10.) Question from Ronald Reed: Will we be able to add chemicals to skid? Disposition: Yes, add to dilution tank. 
HNF-4568, REV. 0

Page 11 of 20

APPENDIX B

REVIEW COMMENT RECORDS 


\section{REVIEW COMMENT RECORD (RCR)}

1. Date $5 / 18 / 99$

3. Project No.

\begin{tabular}{l} 
5. Document Number(s)/Title(s) \\
ECN \#638584 Reconnect SN-216 to U-D Valve Pit \\
\hline 17. Comment Submittal Approval:
\end{tabular}

17. Comment Submittal Approval:

Organization Manager (Optional)

\begin{tabular}{|l|l|}
\hline 6. Program/Project/Building Number & $\begin{array}{l}\text { 7. Reviewer } \\
241-U\end{array}$ \\
\hline
\end{tabular}

10. Agreement with indicated comment disposition(s)
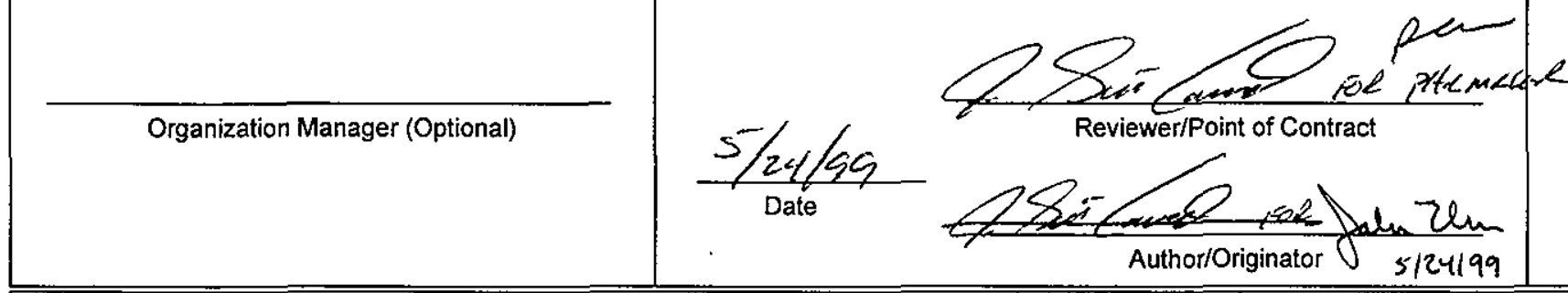

2. Review No.

\section{Page 1 of 1}

8. Organization/Group

Environmental

9. Location/Phone

R1-51 373-1920

11. CLOSED

\begin{tabular}{|c|c|c|c|c|}
\hline $\begin{array}{l}12 . \\
\text { 1tem }\end{array}$ & 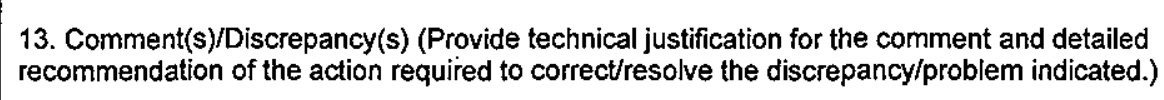 & $\begin{array}{l}\text { 14. Hold } \\
\text { Point }\end{array}$ & 15. Disposition (Provide justification if NOT accepted.) & $\begin{array}{l}16 . \\
\text { Statu: }\end{array}$ \\
\hline 1 & No comment & & & \\
\hline & & & & \\
\hline & & & & \\
\hline & & & & \\
\hline & & & & \\
\hline & & & & \\
\hline & & & & \\
\hline & & & & \\
\hline & & & & \\
\hline & & & & \\
\hline & & & & \\
\hline & & & & \\
\hline
\end{tabular}




\section{REVIEW COMMENT RECORD (RCR)}

\begin{tabular}{|l|l|l|l}
\hline 5. Document Number(s)/Title(s) & 6. Program/Project/Building Number & 7. Reviewer \\
ECN \#638584 Reconnect SN-216 to U-D Valve Pit & $241-U$ & Mike Tipps \\
\hline
\end{tabular}

17. Comment Submittal Approval:

Organization Manager (Optional)
1. Date $5 / 18 / 99$

\section{Project No}

8. Organization/Group

Quality Assurance
10. Agreement with indicated comment disposition(s)

$$
\text { impichest lipen }
$$

$5 \cdot 2+-99$ Date

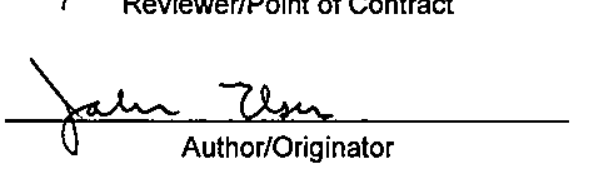

2. Review No.

4. Page 1 of 1

9. Location/Phone

R1-51 373-1920

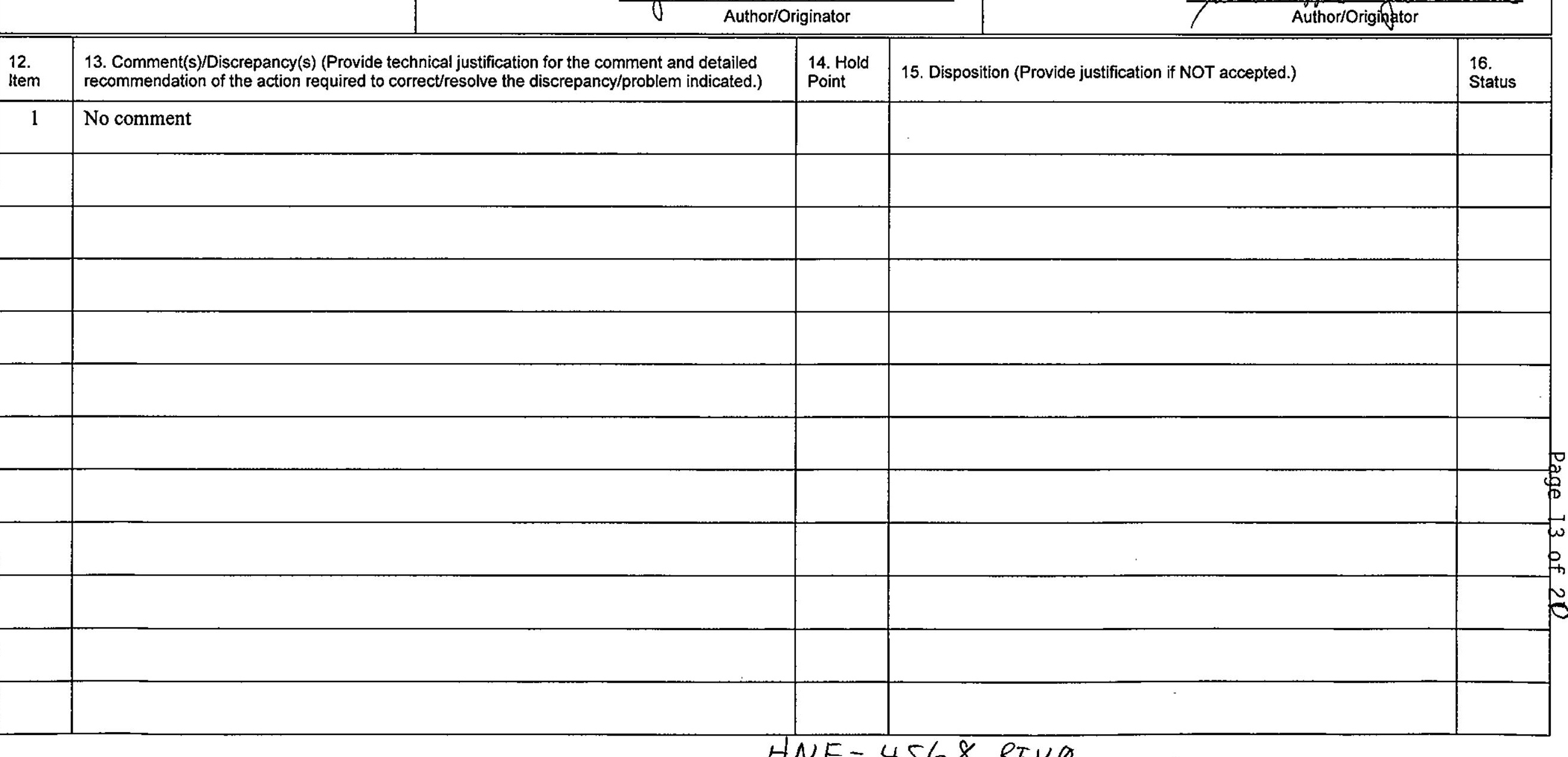




\section{REVIEW COMMENT RECORD (RCR)}

5. Document Number(s)/Title(s)

ECN \#638584 Reconnect SN-216 to U-D Valve Pit

17. Comment Submittal Approval:

Organization Manager (Optional)

\begin{tabular}{l|l} 
6. Program/Project/Building Number & 7. Reviewer \\
$241-\mathrm{U}$ & Kevin J. Hull
\end{tabular}

10. Agreement with indicated comment disposition(s)

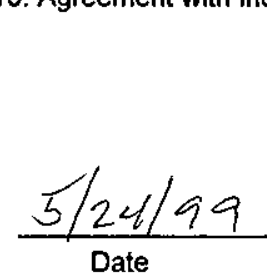

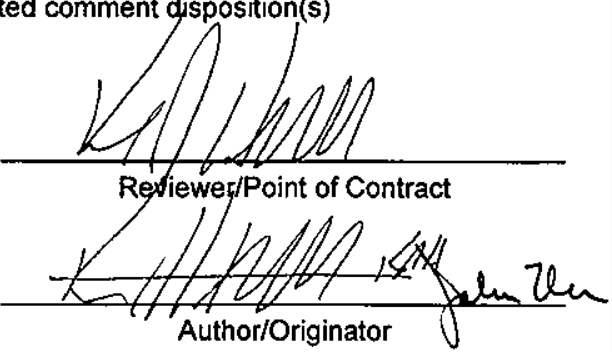

1. Date $5 / 18 / 99$

3. Project No.

2. Review No.

4. Page 1 of 1

8. Organization/Group SST Engineering

9. Location/Phone $376-0145$

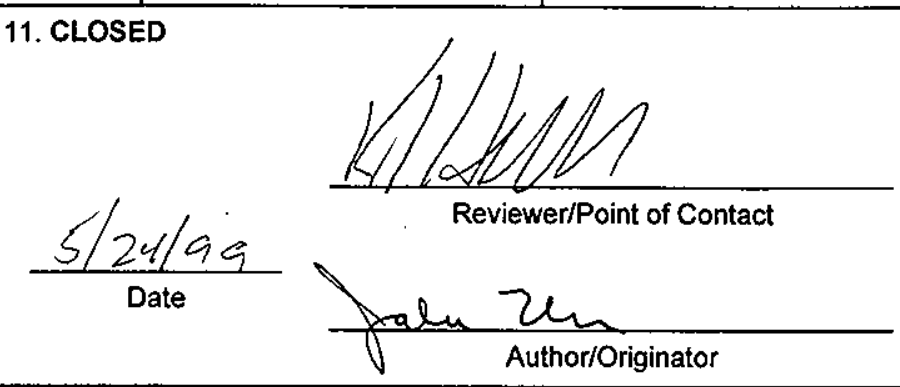

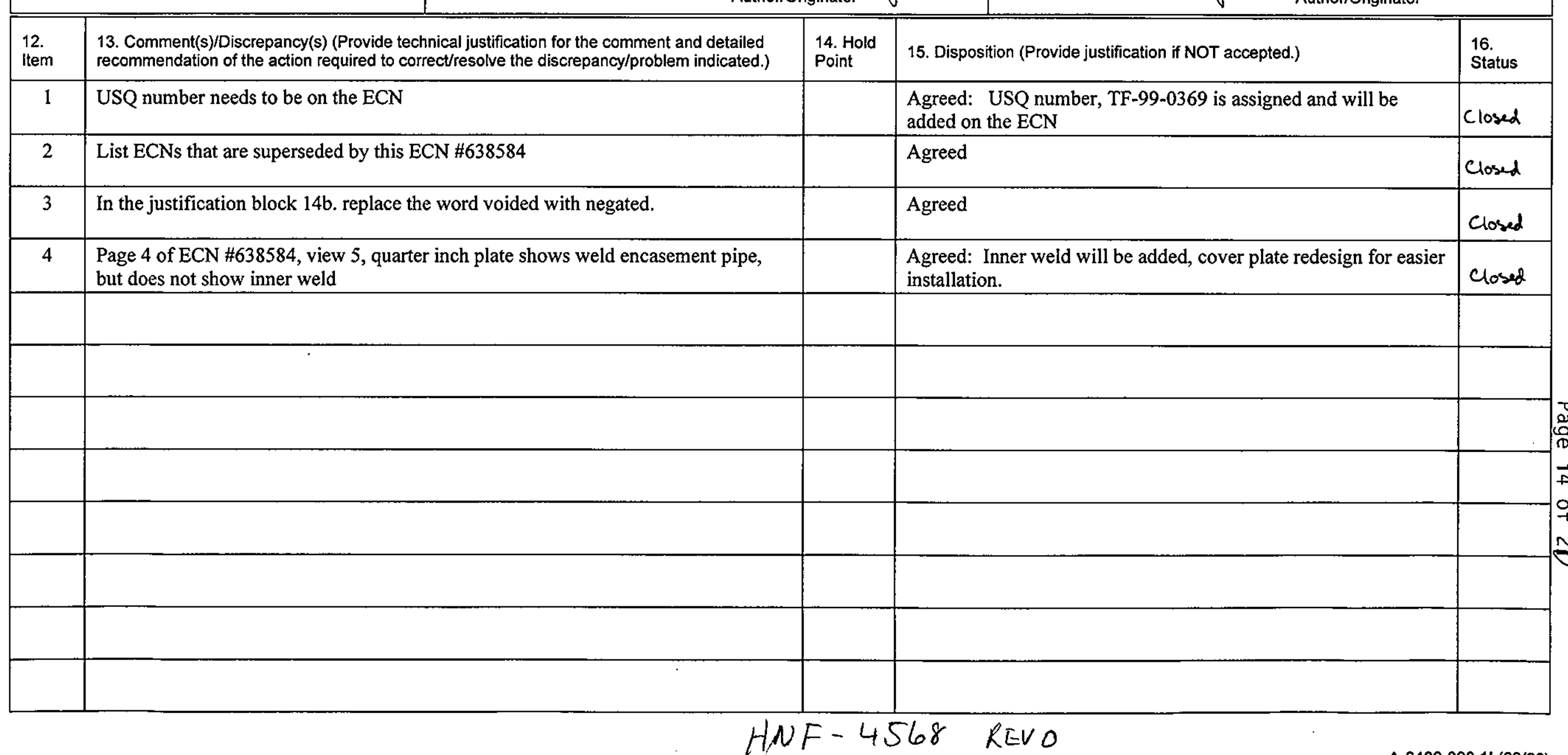




\section{REVIEW COMMENT RECORD (RCR)}

5. Document Number(s)/Title(s)
ECN \#638584 Reconnect SN-216 to U-D Valve Pit

17. Comment Submittal Approval:

Organization Manager (Optional)

\begin{tabular}{l|l|l} 
6. Program/Project/Building Number & 7. Reviewer \\
$241-\mathrm{U}$ & Mike Koch \\
\hline
\end{tabular}

10. Agreement with indicated comment disposition(s)

$$
\text { Nohatrilh }
$$
Reviewer/Point of Contract

$$
\frac{5 / 24 / 99}{\text { Date }}
$$

1. Date $5 / 18 / 99$

3. Project No.

Interim Stabilization Engineering

11. CLOSED

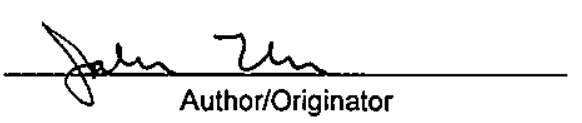

2. Review No.

4. Page 1 of 1

9. Location/Phone

2704-HV 373-2699

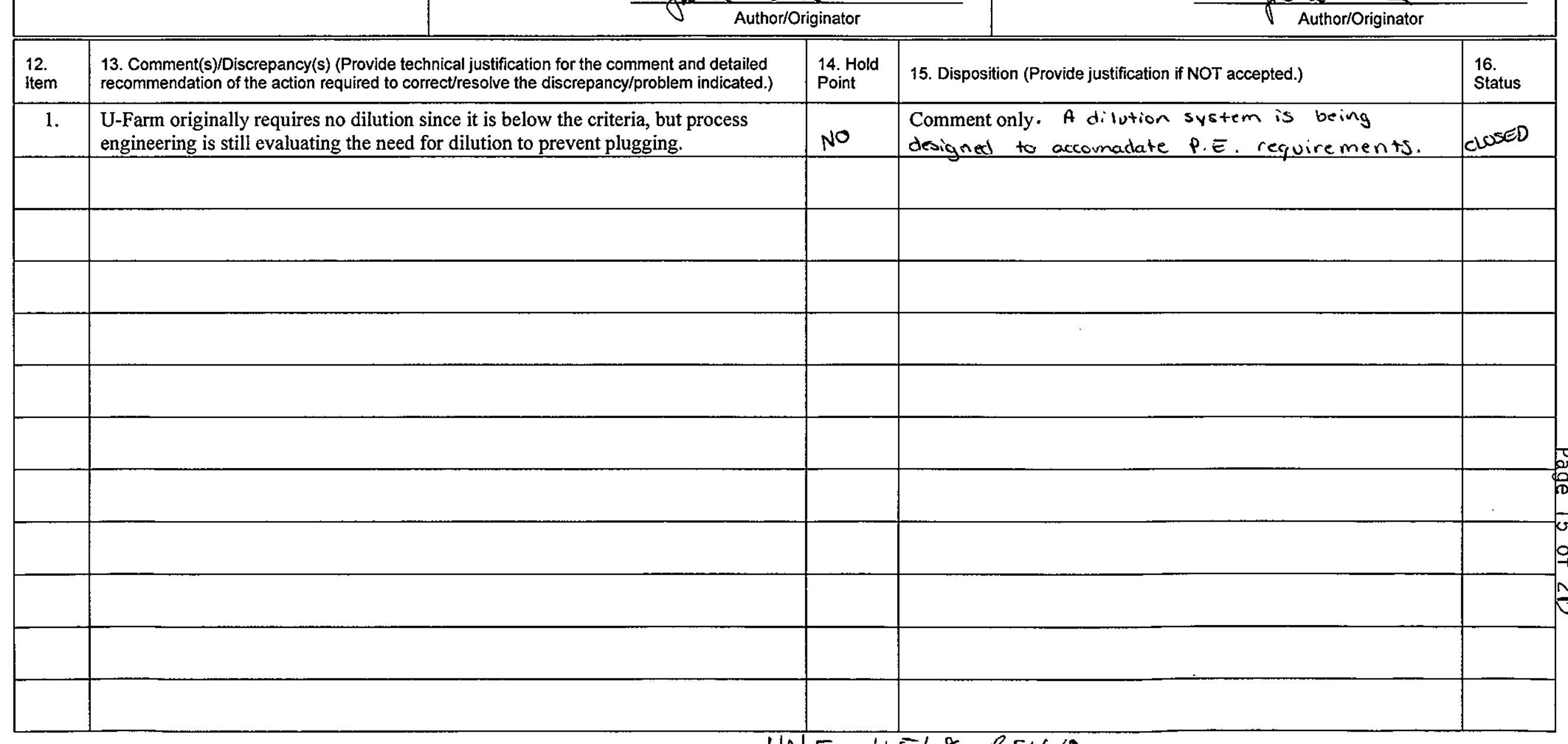




\section{REVIEW COMMENT RECORD (RCR)}

\begin{tabular}{|l|l|l|}
\hline 5. Document Number(s)/Title(s) & 6. Program/Project/Building Number & 7. Reviewer \\
ECN \#638584 Reconnect SN-216 to U-D Valve Pit & $241-\mathrm{U}$ & Steve Krogsrud \\
\hline
\end{tabular}

17. Comment Submittal Approval:

Organization Manager (Optional)

10. Agreement with indicated comment disposition(s)
1. Date $5 / 18 / 99$

\section{Project No.}

8. Organization/Group

Operation Support

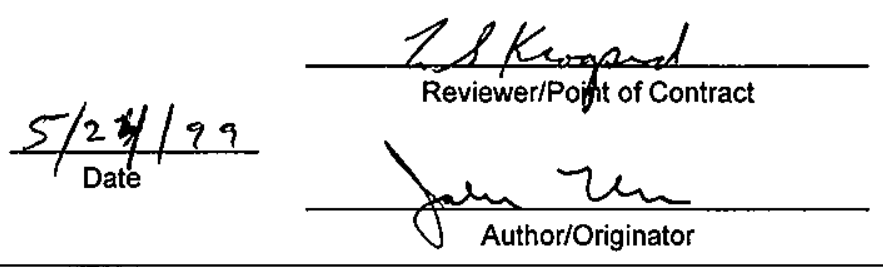

2. Review No.

4. Page 1 of 1

9. Location/Phone

T4-07 372-2302

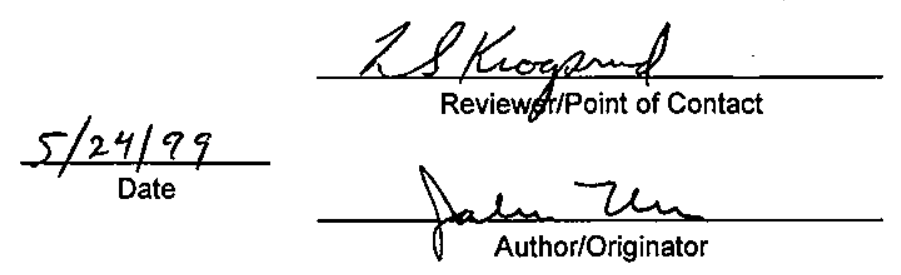

\begin{tabular}{|c|c|c|c|c|}
\hline $\begin{array}{l}12 . \\
\text { ltem }\end{array}$ & $\begin{array}{l}\text { 13. Comment(s)/Discrepancy(s) (Provide technical justification for the comment and detailed } \\
\text { recommendation of the action required to correct/resolve the discrepancy/problem indicated.) }\end{array}$ & $\begin{array}{l}\text { 14. Hold } \\
\text { Point }\end{array}$ & 15. Disposition (Provide justification if NOT accepted.) & $\begin{array}{l}16 . \\
\text { Status }\end{array}$ \\
\hline 1 & No comment & & & \\
\hline & & & & \\
\hline & & & & \\
\hline & & & . & \\
\hline & . & & & \\
\hline & & & & \\
\hline & . & & & \\
\hline & & & & \\
\hline & & & & \\
\hline & & & & \\
\hline & & & & \\
\hline & & & & \\
\hline
\end{tabular}




\section{REVIEW COMMENT RECORD (RCR)}

\begin{tabular}{|l|l|}
\hline 5. Document Number(s)/Title(s) & $\begin{array}{l}6 . \text { Program/Project/Building Number } \\
\text { ECN \#638584 }\end{array}$ \\
\hline
\end{tabular}

17. Comment Submittal Approval:

Organization Manager (Optional)

10. Agreement with indicated comment disposition(s)
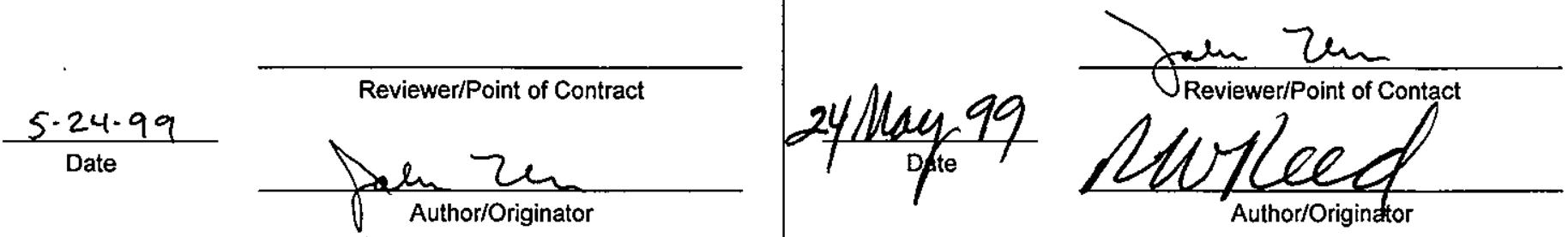

Author/Originator

\begin{tabular}{|c|c|c|c|c|}
\hline $\begin{array}{l}12 . \\
\text { Item }\end{array}$ & $\begin{array}{l}\text { 13. Comment(s)/Discrepancy(s) (Provide technical justification for the comment and detailed } \\
\text { recommendation of the action required to correct/resolve the discrepancy/problem indicated.) }\end{array}$ & $\begin{array}{l}\text { 14. Hold } \\
\text { Point }\end{array}$ & 15. Disposition (Provide justification if NOT accepted.) & $\begin{array}{l}16 . \\
\text { Status }\end{array}$ \\
\hline 1 & Heat trace is not included on this ECN. & $y e_{s-24}^{x-2}$ & $\begin{array}{l}\text { Reject; Heat trace will be on a separate ECN dependent upon as } \\
\text { a found field condition. }\end{array}$ & Closed \\
\hline 2 & Confirm chemical addition requirements and location of mixing. (hold point) & $X$ & $\begin{array}{l}\text { Accept; Process Engineering shall determine chemical addition } \\
\text { requirements, addition shall take place at dilution skid if } \\
\text { necessary }\end{array}$ & Closed \\
\hline 3 & $\begin{array}{l}\text { Primary line should be tested for a design pressure of } 400 \text { psi. Hydro test primary to } \\
600 \text { psi. }\end{array}$ & & $\begin{array}{l}\text { Accept; Since a plug is possible the line may experience elevated } \\
\text { pressures for unplugging. Hydro test should prove line integrity } \\
\text { @ } 600 \text { psi (primary) and @ } 90 \text { psi (encasement) }\end{array}$ & Closed \\
\hline 4 & Was there a project associated with the old work? & & Yes; B-533 and B-231 & Closed \\
\hline 5 & Is drawing $\mathrm{H}-2-31750$ to be used for the pipe code materials. & & Yes; Identical material called out in detail 9. & Closed \\
\hline 6 & $\begin{array}{l}\text { On page } 4 \text { change plate to go over the encasement, this will reduce the tight } \\
\text { tolerance and ease fabrication. }\end{array}$ & & Accept & Clased \\
\hline 7 & On page 4 note 1 , "and .... and or butt welded cap". & & $\begin{array}{l}\text { Reject; Note } 1 \text { wording clarified. Weld material detail on cap } \\
\text { specified socket weld. }\end{array}$ & Closed \\
\hline 8 & On page 7 add melt through on weld symbol & & Reject; Melt through reinforcement not needed. & Closed \\
\hline & & & & \\
\hline & & & & \\
\hline & & & & \\
\hline
\end{tabular}




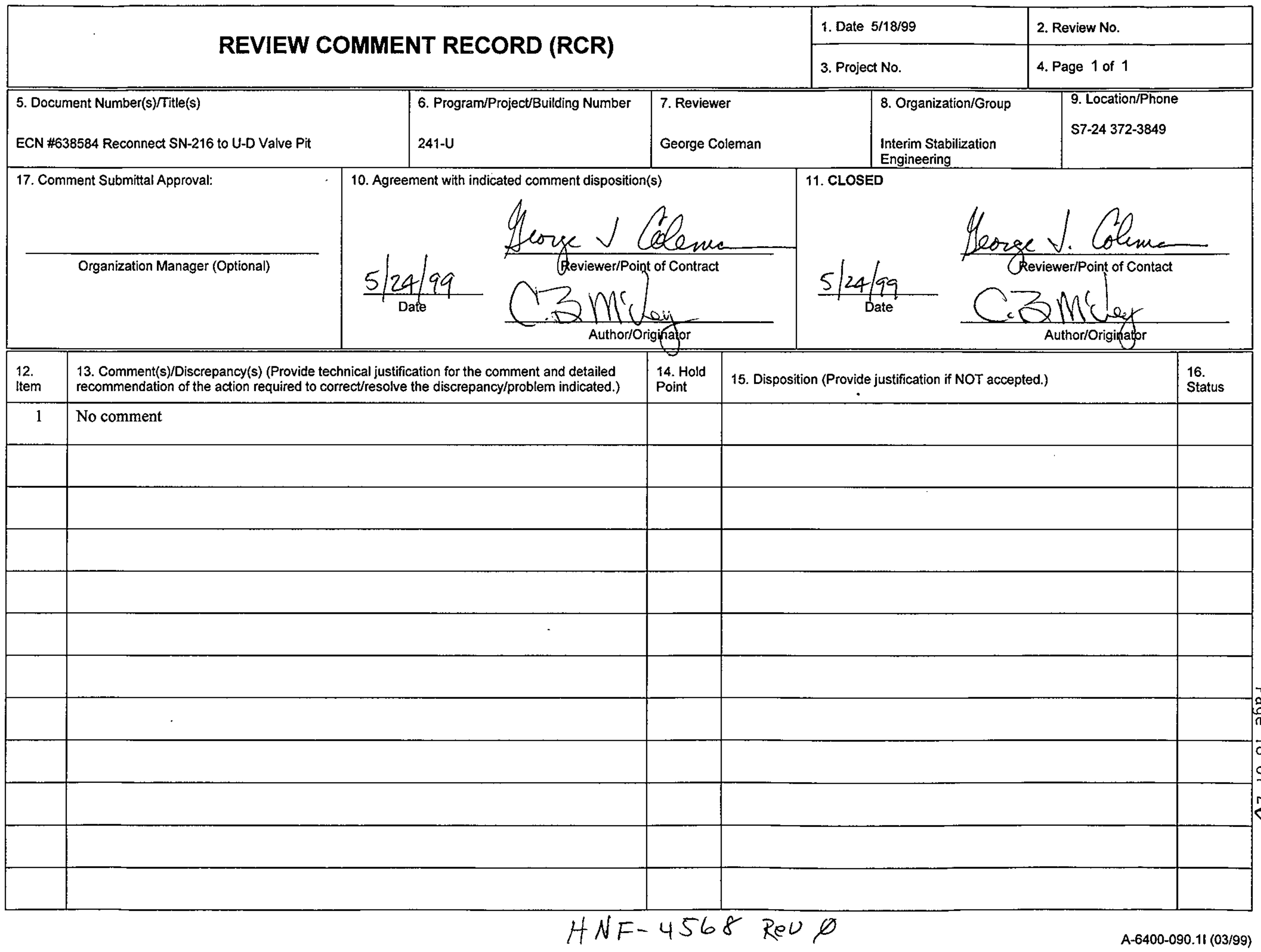




\section{REVIEW COMMENT RECORD (RCR)}

5. Document Number(s)/Title(s)

ECN \#638584 Reconnect SN-216 to U-D Valve Pit

6. Program/Project/Building Number

$241-U$

1. Date $5 / 18 / 99$

2. Review No.

3. Project No.

4. Page 1 of 1

7. Reviewer

Rich Larson

SST Engineering

9. Location/Phone

T4-07 373-9100

17. Comment Submittal Approval:

10. Agreement with indicated comment disposition(s)

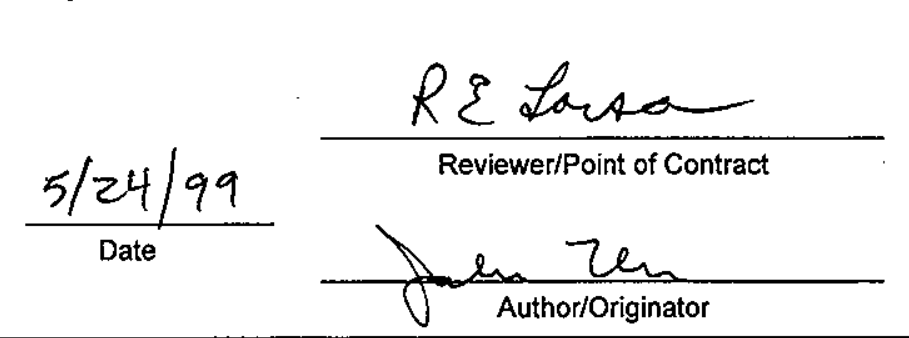

11. CLOSED
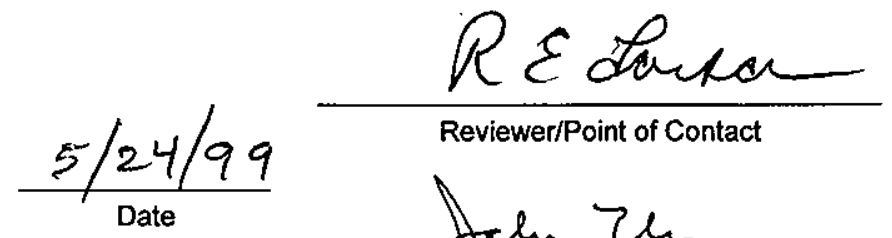

Organization Manager (Optional)

13. Comment(s)/Discrepancy(s) (Provide technical justification for the comment and detailed
recommendation of the action required to correct/resolve the discrepancy/problem indicated.)

12.
Item recommendation of the action required to correct/resolve the discrepancy/problem indicated.)

Block 20 of ECN \#638584 identify documents to be affected.

ECN \#638584 needs to include the design review chairman.

3 On page 7, what is the maximum pressure of pump that can be set?

\begin{tabular}{|l|l|l|}
$\begin{array}{l}\text { 14. Hold } \\
\text { Point }\end{array}$ & 15. Disposition (Provide justification if NOT accepted.) & $\begin{array}{l}16 . \\
\text { Status }\end{array}$ \\
\hline & Agreed & Closed \\
\hline & Agreed & Closed \\
\hline & Pressure set point 187 lbs. for pump shut down. & Closed \\
\hline
\end{tabular}

Reviewer/Point of Contact

$\ln \mathrm{Ch}$ Author/Originator

\begin{tabular}{|l}
\hline \\
\hline \\
\hline \\
\hline \\
\hline \\
\hline \\
\hline \\
\hline
\end{tabular}

On page 7 , what is the maximum pressure of pump that can be set?




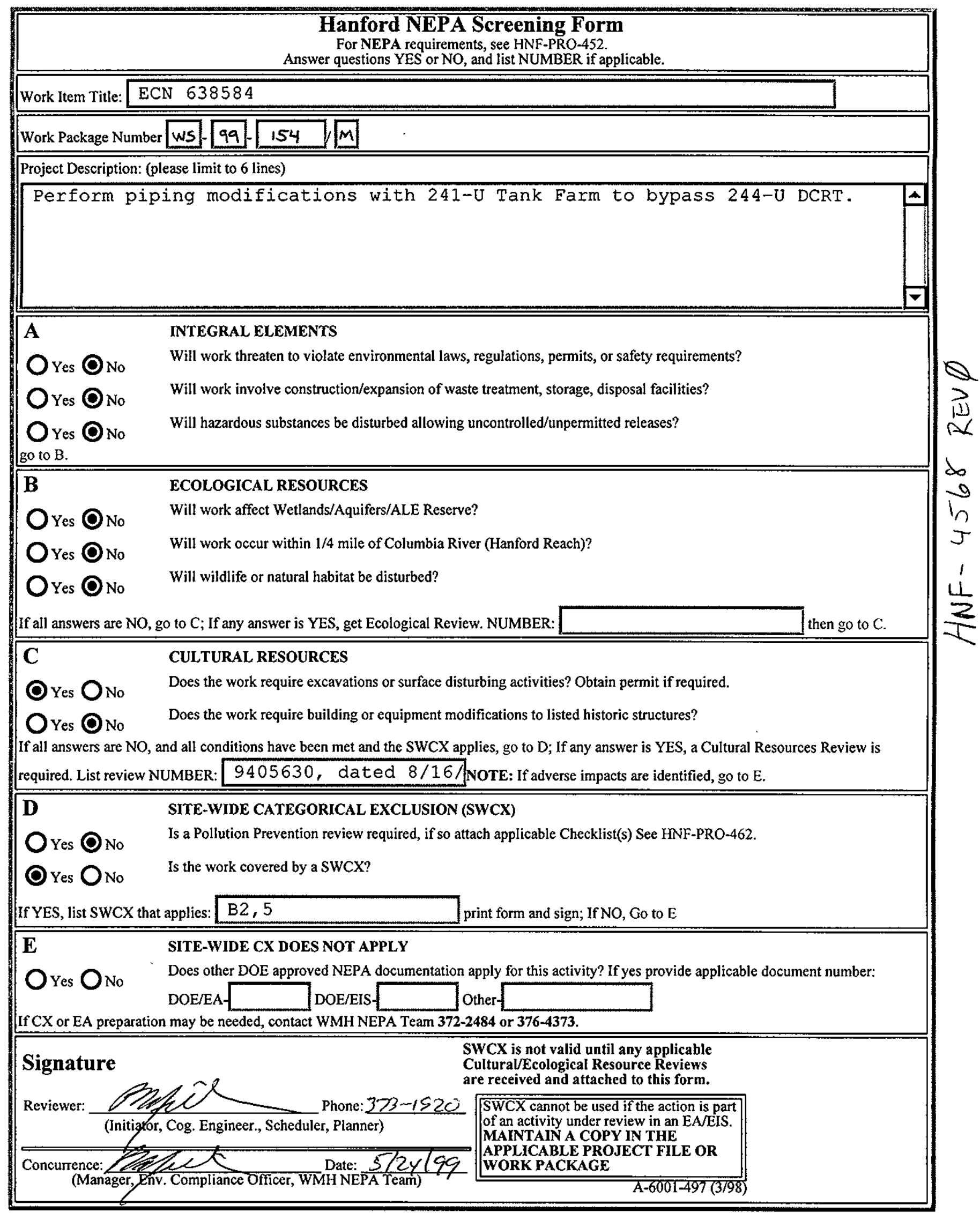




\section{DISTRIBUTION SHEET}

To

Distribution

Project Title/Work Order

Design Review Report for $\mathrm{ECN} 638538$ (Reconnect SN-216 to U-D Valve Pit)

\begin{tabular}{|l}
\hline \\
\hline Elsen, J. J. \\
\hline Hull, K. J. \\
\hline Koch, M. R. \\
\hline Krogsrud, L. S. \\
\hline Larsen, R. E. \\
\hline McVey, C. B. \\
\hline Miller, P. C. \\
\hline Reed, R. W. \\
\hline Tipps, M. A. \\
\hline
\end{tabular}

Name
From
Interim Stabilization Engineering

ECN No. 638584

\begin{tabular}{|l|c|l|c|l|}
\hline MSIN & $\begin{array}{c}\text { Text } \\
\text { With All } \\
\text { Attach. }\end{array}$ & Text Only & $\begin{array}{c}\text { Attach./ } \\
\text { Appendix } \\
\text { Only }\end{array}$ & $\begin{array}{c}\text { EDT/ECN } \\
\text { Only }\end{array}$ \\
\hline S7-24 & $X$ & & & \\
\hline T4-07 & $X$ & & & \\
\hline S7-24 & $X$ & & & \\
\hline T4-07 & $X$ & & & \\
\hline T4-07 & $X$ & & & \\
\hline S7-24 & $X$ & & & \\
\hline R1-51 & $X$ & & & \\
\hline T4-07 & $X$ & & & \\
\hline S7-34 & $X$ & & & \\
\hline
\end{tabular}

Page 1 of 1

EDT No. 626386
Date $6 / 2 / 99$

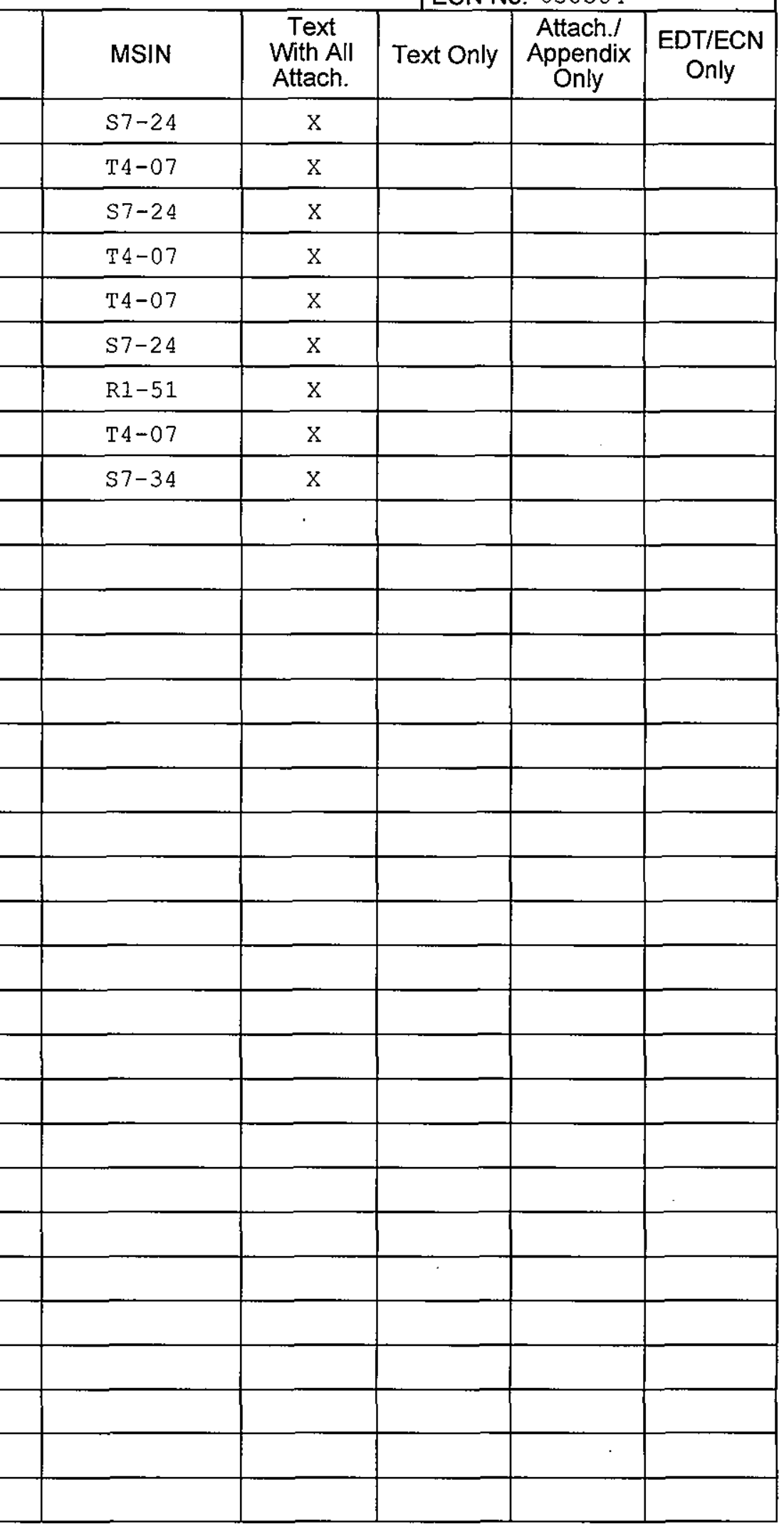

